All medical records and imaging studies were reviewed.

Results Number of Deliveries over the 5-year study period was 25443 of which 4100 (16\%) were un-booked. Dilated cistern magna was diagnosed in 26 (0.12\%) fetal scans (15 male and 11 females). Post natal scans were done in 20/26 (77\%) and not done in 6/26 $(23 \%)$ of cases.

Of the 20 post natal scans done $12(60 \%)$ were normal and 8 (40\%) were abnormal. The following abnormalities were detected: $4(50 \%)$ dandy walker complex, $2(25 \%)$ corpus collasum dysgenesis and $2(25 \%)$ cerebellar hypoplasia. Neuro-developmental assessment was reported as normal in $60 \%$ of the isolated mega cistern magna patients.

Conclusion The association of mega cisterna magna with major CNS anomalies is high in our population. Post natal neuroimaging confirmation of all abnormal fetal sonography is required. Long term neurocognative assessment and follow up is essential for this population.

\section{SPECTRUM OF CRANIAL ULTRASOUND FINDINGS IN NEWBORNS UNDER 26 WEEKS GESTATION OVER 10 YEAR PERIOD IN A TERTIARY NEONATAL UNIT}

doi:10.1136/archdischild-2012-302724.1057

${ }^{1} \mathrm{~J}$ Kapur, ${ }^{2} \mathrm{G}$ Cattell, ${ }^{1} \mathrm{SV}$ Rasiah. ${ }^{1}$ Department of Neonatology; ${ }^{2}$ Department of Radiology, Birmingham Women's NHS Foundation Trust, Birmingham, UK

Background and Aims Cranial ultrasonography is an integral part of routine neonatal screening in extreme preterm neonates. To audit the spectrum of cranial ultrasound scan findings in preterms less than $26+0$ weeks gestation.

Methods We reviewed all cranial ultrasound findings performed in babies less than 26+0 weeks gestation between 1999-2008. Demographic data was collected using a proforma. Information regarding cranial ultrasound scans on day 1-4, day 7 and day 28 of life for live born babies admitted to the neonatal unit was collected.

Results The results are tabulated in the tables attached. Table 1 shows the demographic details and table 2 shows the spectrum of cranial ultrasound findings.

Abstract 1057 Table 1 Demographic details

\begin{tabular}{lcccc}
\hline $\begin{array}{l}\text { Gestation } \\
\text { (weeks) }\end{array}$ & $\begin{array}{c}\text { Number of } \\
\text { babies }\end{array}$ & $\begin{array}{c}\text { Median birth } \\
\text { weight(grams) }\end{array}$ & $\begin{array}{c}\text { Apgar at 1 } \\
\text { minute(median) }\end{array}$ & $\begin{array}{c}\text { Apgar at 5 } \\
\text { minutes(median) }\end{array}$ \\
\hline $23-23+6$ & 11 & 630 & 3 & 7 \\
$24-24+6$ & 50 & 660 & 4 & 8 \\
$25-25+6$ & 69 & 734 & 5 & 8 \\
\hline
\end{tabular}

Conclusion Extremely preterm babies ( 23 and 24 weeks gestation) had a higher incidence of abnormal cranial ultrasound scans compared to those over $25+0$ weeks gestation. This is associated with a high risk of morbidity and mortality. This information is important when counselling parents and for prognosticating outcomes.

\section{NEW SEGMENTATION METHOD SHOWS EFFECTS OF PREMATURITY ON CEREBRAL TISSUE VOLUMES AT TERM}

doi:10.1136/archdischild-2012-302724.1058
'L Gui, ${ }^{2} \mathrm{~F}$ Lazeyras, ${ }^{3} \mathrm{~A}$ Truttmann, ${ }^{1} \mathrm{C}$ Borradori Tolsa, 'PS Hüppi. ${ }^{1}$ Pediatrics, Children's

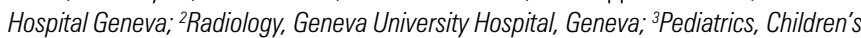
Hospital Lausanne, Lausanne, Switzerland

Background and Aim Longitudinal studies show that premature birth increases infants' risk for mental and motor development deficits. Our aim was to investigate the influence of prematurity on cerebral tissue volumes at term obtained with a novel fully automatic segmentation method.

Methods 62 preterm infants (GA 27.7 $\pm 1.3 w k s$ ) and 15 term-born infants (GA $40 \pm 1.1 \mathrm{wks}$ ) were scanned at term-equivalent age (GA $40.5 \pm 1.5 \mathrm{wks})$. T1 and T2 MR images were segmented with a novel atlas-free automatic method based on morphological constraints Each brain was separated into the two hemispheres, cortical and subcortical gray matter, myelinated and unmyelinated white matter, brainstem, cerebellum and CSF.

Results Linear regression models were fitted to study the dependency of tissue volumes on GA at birth, GA at scan and intracranial volume. Models show significant dependence on GA at birth for cortical gray matter ( $\mathrm{Beta}=0.270, \mathrm{P}=0.000, \mathrm{R}^{2}=0.818$ ), unmyelinated white matter (Beta $=0.196, \mathrm{P}=0.03, \mathrm{R}^{2}=0.575$ ), cerebellum (Beta $=0.348$, $\mathrm{P}=0.000, \mathrm{R}^{2}=0.648$ ) and CSF (Beta $=-0.329, \mathrm{P}=0.000, \mathrm{R}^{2}=0.708$ ).

Wilcoxon Signed Ranks tests showed significantly larger unmyelinated white matter volumes in the right hemisphere compared to the left hemisphere $(\mathrm{Z}=-4.826, \mathrm{P}=0.000)$, and significantly larger total volumes of the right hemisphere compared to the left hemisphere $(Z=-3.486, P=0.000)$

Conclusions Reliable volume assessments were derived from the new automatic segmentation. CSF volumes at term increased with lower GA at birth, while cortical gray matter, unmyelinated white matter and cerebellum volumes at term increased with GA at birth, suggesting impaired growth of these tissues associated with prematurity. Cerebral asymmetry was present at term for both preterm and term infants.

\section{MYELIN IS DIFFERENTIALLY ASSOCIATED WITH RESTING STATE FUNCTIONAL CONNECTIVITY IN ADULTS WHO WERE BORN VERY PRETERM AND CONTROLS}

doi:10.1136/archdischild-2012-302724.1059

${ }^{1} \mathrm{~S}$ Froudist Walsh, ${ }^{2} \mathrm{SH}$ Kolind, 'KW Nam, 'M Walshe, ${ }^{2} \mathrm{~J}$ 0'Muircheartaigh, ${ }^{2} \mathrm{~S}$ Deoni, ${ }^{2} \mathrm{SC}$ Williams, 'RM Murray, 'MP Allin, 'C Nosarti. 'Department of Psychosis Studies, ${ }^{2}$ Centre for Neuroimaging Sciences, Institute of Psychiatry, King's College London, London, UK

Background and Aims Diffuse white matter injury is the most common form of brain injury following very preterm (VPT) birth This may reflect altered myelination, which could affect both neurodevelopment and neuronal communication. We investigated whether myelin in the corpus callosum (CC) was associated with functional connectivity; and if these associations differed between young adults born VPT and controls.

Methods 9 VPT-born adults and 13 controls (age 26-28 years) underwent resting state functional MRI (rs-fMRI), diffusion MRI and $\mathrm{mcDESPOT}$, a novel neuroimaging method which provides an in vivo estimate of myelin water fraction (MWF). MWF was calculated along the CC. The default mode network (DMN), which

Abstract 1057 Table 2 Spectrum of cranial ultrasound findings

\begin{tabular}{cclcclcccc}
\hline Gestation & $\begin{array}{c}\text { Day 1-4 } \\
\text { Normal }\end{array}$ & $\begin{array}{l}\text { Day 1-4 } \\
\text { Abnormal }\end{array}$ & $\begin{array}{c}\text { No results } \\
\text { available/died }\end{array}$ & $\begin{array}{c}\text { Day } 7 \\
\text { Normal }\end{array}$ & $\begin{array}{l}\text { Day } 7 \\
\text { Abnormal }\end{array}$ & $\begin{array}{c}\text { No results } \\
\text { available/died }\end{array}$ & $\begin{array}{c}\text { Day 28 } \\
\text { Normal }\end{array}$ & $\begin{array}{l}\text { Day 28 } \\
\text { Abnormal }\end{array}$ & $\begin{array}{c}\text { No results available/ } \\
\text { lost to follow up/died }\end{array}$ \\
\hline $23-23+6$ & 6 & $5(45 \%)$ & 0 & 4 & $7(63 \%)$ & 0 & 3 & $7(63 \%)$ & 1 \\
$24-24+6$ & 24 & $19(38 \%)$ & 7 & 13 & $23(46 \%)$ & 14 & 15 & $14(28 \%)$ & 23 \\
$25-25+6$ & 44 & $17(24.6 \%)$ & 8 & 39 & $18(26 \%)$ & 12 & 28 & $12(17.3 \%)$ & 29 \\
\hline
\end{tabular}

